\title{
Domestic violence among Omani women: prevalence, risk factors and help-seeking behaviour
}

Asma Al Kendi, ${ }^{1}$ Nohour Al Shidhani ${ }^{1}$ and Maisa Al Kiyumi ${ }^{2}$

${ }^{1}$ Directorate-General of Primary Health Care, Ministry of Health, Muscat, Oman. ${ }^{2}$ Department of Family Medicine and Public Health, Sultan Qaboos University Hospital, Muscat, Oman. (Correspondence to: Maisa Al Kiyumi; maysa8172@gmail.com).

\begin{abstract}
Background: Domestic violence is a serious and often underreported problem. No studies on domestic violence have been conducted in Oman.

Aims: This study determined the prevalence and risk factors of emotional and/or physical domestic violence in Omani women, and the help-seeking behaviour of those experiencing domestic violence.

Methods: This cross-sectional study in 2019 included literate women aged 18-60 years old attending primary health care centres in Muscat region. A self-administered questionnaire was used to record the characteristics of the women and determine the prevalence of emotional and physical domestic violence. Logistic regression analysis was used to determine risk factors for domestic violence.

Results: Of 1051 women approached, 978 agreed to participate. Mean age of the women was 30.6 (standard deviation 6.9) years. Domestic violence was reported by $28.8 \%$ (282/978) of women: $21.0 \%$ (205/978) had experienced emotional domestic violence, $18.0 \%$ (176/978) physical domestic violence and 10.1\% (99) both emotional and physical domestic violence. Domestic violence was significantly associated with husband's alcohol consumption (odds ratio $(O R)=9.85,95 \%$ confidence intervals (CI): 1.00-96.94), feeling depressed ( $\mathrm{OR}=2.90,95 \% \mathrm{CI}: 1.75-4.81)$, insomnia (OR $=2.54,95 \% \mathrm{CI}: 1.57-4.10)$ and somatic symptoms (OR $=1.73,95 \%$ CI: 1.08-2.78). Only 5.4\% (11/205) of women experiencing emotional violence and $6.3 \%$ (11/176) experiencing physical violence had sought help from their doctors.
\end{abstract}

Conclusion: Emotional and physical domestic violence against women is common in Oman and is associated with poor health outcomes. Addressing domestic violence in Oman is important and requires collaboration between different sectors.

Keywords: domestic violence, women, prevalence, risk factors, Oman

Citation: Al Kendi A; Al Shidhani N; Al Kiyumi M. Domestic violence among Omani women: prevalence, risk factors and help-seeking behaviour. East Mediterr Health J. 2021;27(3):242-249. https://doi.org/10.26719/2021.27.3.242

Received: 06/10/19; accepted: 08/03/20

Copyright (C) World Health Organization (WHO) 2021. Open Access. Some rights reserved. This work is available under the CC BY-NC-SA 3.o IGO license (https://creativecommons.org/licenses/by-nc-sa/3.o/igo).

\section{Introduction}

Domestic violence is a common and serious problem that is often underreported and under-recognized (1). The United Nations defines violence against women as "any act of gender-based violence that results in, or is likely to result in, physical, sexual, or mental harm or suffering to women, including threats of such acts, coercion or arbitrary deprivation of liberty, whether occurring in public or in private life" (2).

Worldwide, it is estimated that one in three women suffers from some form of domestic violence (3). Studies conducted in Lebanon, Jordan, Egypt and Saudi Arabia reported a prevalence of domestic violence of $35 \%, 24 \%$, $26 \%$ and $34 \%$, respectively $(4-7)$. The wide variation in the prevalence rates in these studies could be attributed to differences in the methods used.

Risk factors for domestic violence are similar for both pregnant and non-pregnant women (8). Being married, living within large families (more than five members), low educational level, and living in urban areas have been reported as significant predictors of emotional violence against women (9). Moreover, a recent systematic review substantiated that unplanned pregnancy and having parents with less than a high-school education were the strongest modifiable predictors of domestic violence against women (10).

The impact of domestic violence against women on their health is well recognized (11). These effects include but are not limited to: injury, unintended pregnancy, miscarriage, sexually transmitted infections, and mental disorders (3). A systematic review confirmed that about one third of female homicides were a result of intimate partner violence (12). Importantly, the negative effects of domestic violence can extend to children who grow up in families where domestic violence occurs. Such children may be prone to behavioural and emotional instability (3). Similarly, intimate partner violence during pregnancy may lead to devastating effects on birth outcome such as low birth weight and prematurity (13).

While there have been no published study on domestic violence ression concluded that depression during pregnancy was strongly associated with marital conflict (adjusted odds ratio (OR):13.83, P < 0.001) (14). However, marital conflict was not appropriately defined 
and measured using a well-validated and reliable scale in that study. Therefore, there is an urgent need to study domestic violence in Omani women in more depth. We aimed to determine the prevalence and risk factors of emotional and/or physical domestic violence among Omani women attending primary health care centres in Willayat Al-Seeb, Muscat, and the help-seeking behaviour of these women

\section{Methods}

\section{Study design and sample}

This was a cross-sectional study to determine the prevalence of domestic violence among literate Omani women. The study was conducted from 1 April 2019 to 30 July 2019 in the most populated wilayat of Muscat governorate. We randomly selected four out of nine primary health care centres (PHC) in the area for this study. The sample size for each selected health centre was proportional to its population size. It should be noted that the women who attended the PHC centres included some who were originally from different regions of Oman, but were living in the Muscat region for various reasons (e.g. work, education).

We calculated the sample size needed using the nMaster 2.0 software (15) based on an expected prevalence of domestic violence of $35 \%$, absolute precision of 3 and a desired confidence level of $95 \%$. The sample size was adjusted to a population size of 30000 women (based on the estimated number of female attendees aged between 18 and 60 years old who attended the four PHC centres during the study period). Thus, the final sample size needed 940 women.

We used a consecutive sampling method to recruit women. Women attending the selected PHC centres who were literate (able to read and write), aged 18-60 years and not seriously ill (i.e. not needing to be seen as an emergency) were invited by a trained triage nurse to participate in this study. Written informed consent was obtained. Women who consented to participate were given a self-administered questionnaire to complete anonymously in a private place. For women who declined to participate, the nurse documented their reasons for not participating.

\section{Questionnaire}

The self-administered questionnaire had two parts. Part one asked about sociodemographic characteristics such as age, educational level (of the participant, her husband and her parents), family income, occupation of the participant and her husband, number of household family members, and smoking and alcohol consumption. Part two of the questionnaire consisted of the Arabic version of the NorVold Domestic Abuse Questionnaire (NORAQ). NORAQ is a self-administered, reliable and well-validated scale to determine the prevalence of emotional, physical and sexual violence (16). Its sensitivity ranges from $75 \%$ for emotional violence to $96 \%$ for physical violence. Specificity is $98 \%$ and $85 \%$ for emotional and physical abuse, respectively (17). This questionnaire consists of the following parts: 1) General physical and mental health assessments; 2) Questions about emotional, physical and sexual violence; and 3) General questions related to violence including perpetrators and help-seeking behaviour. We did not include sexual violence in our study because many women were reluctant to answer questions on sexual violence during the initial pilot phase.

Participants were classified as having mild, moderate or severe emotional domestic violence if they answered "yes", respectively, to: (i) Has anybody, systematically and for a long period, tried to repress, degrade or humiliate you?; (ii) Has anybody, systematically and by threat or force, tried to limit your contact with others, or totally controlled what you may and may not do?; (iii) Have you lived in fear because somebody, systematically and for a long period, threatened you or somebody close to you? (16). Similarly, physical violence was categorized as mild, moderate or severe if the woman responded positively to any of the following questions, respectively: (i) Has anybody hit you, smacked your face or held you firmly against your will?; (ii) Has anybody hit you with his/her fist(s) or with a hard object, kicked you, pushed you violently, given you a beating, thrashed you or done anything similar to you?; (iii) Has anybody threatened your life by, for instance, trying to strangle you, displaying a weapon or a knife, or by any other similar act? (16).

\section{Statistical analysis}

We used SPSS, version 24 for all statistical analyses. We did a univariate analysis to test the association between domestic violence and different variables using the chisquared test. We also did a logistic regression analysis to adjust for the effects of confounders and odds ratios (OR) and 95\% confidence intervals (CI) are reported. We considered a $P$-value of $\leq 0.05$ to be statistically significant.

\section{Ethical approval}

Directorate General of Planning and Studies, Ministry of Health gave approval for the study (MOH/DGPS/MG34/2018).

\section{Results}

Out of 1051 women who were invited to participate in our study, 978 agreed to fill in the questionnaire, a 93\% response rate. The main reason for not agreeing to participate was a lack of time; those who did not participate were similar to those who did in terms of sociodemographic characteristics.

The mean age of the participants was 30.6 (standard deviation 6.9) years, and most of them (821 out of 978 , $84.0 \%$ ) were married. More than two thirds of the currently married women had been married $\leq 10$ years. In addition, most of participants (601 out of $978,61.5 \%$ ) were living in a family with more than 5 members. More than half of the women who had experienced domestic violence were aged between 18 and 30 years old (54.3\%; 153/282) and most were married (77.7\%; 219/282). Furthermore, 90.8\% 
(256/282) of women experiencing domestic violence had a secondary school or higher education and $64.9 \%$ (183/282) of them were living in a house with five or more family members. Table 1 shows the baseline characteristics of our sample according to experience of domestic violence.

The prevalence of overall and type of life-long domestic violence based on the Arabic NorVold Domestic Abuse Questionnaire (NORAQ) is shown in Table 2. The overall prevalence of domestic violence was $28.8 \%$ (282/978). Emotional domestic violence was more common than physical domestic violence, prevalence $21.0 \%$ and $18.0 \%$, respectively. Ninety-nine women (10.1\%) reported being experiencing both emotional and physical domestic violence.

The univariate analysis showed that being divorced $(P<0.001)$, having a low income $(P<0.001)$ and alcohol consumption of the husband $(P<0.001)$ were significant predictors of domestic violence (Table 1). More women who had experienced domestic violence than those who had not reported feeling sad with loss of interest $(P<0.001)$, having sleep problems $(P<0.001)$ and suffering from somatic symptoms such as abdominal pain and headache $(P<0.001)$ (Table 1$)$.

The logistic regression analysis showed that alcohol consumption of the husband (OR $=9.85$ 95\% CI: $1.00-$ 96.94; $P=0.050)$, feeling sad with loss of interest $(\mathrm{OR}=2.90,95 \% \mathrm{CI}: 1.75-4.81 ; \mathrm{P}<0.001)$, sleep disturbance $(\mathrm{OR}=2.54, \quad 95 \% \mathrm{CI}: 1.57-4.10 ; \quad \mathrm{P}<0.001)$ and somatic symptoms (OR $=1.73,95 \% \mathrm{CI}: 1.08-2.78, P=0.022)$ were significantly associated with domestic violence (Table 3).

Regarding the perpetrators of the domestic violence, $30.5 \%(86 / 282)$ of the women reported that the abuser was their father, $28.4 \%(80 / 282)$ said it was their husband or ex-husband and $27.3 \%$ (77/282) said it was their brother(s) (Figure 1). The rest of the participants reported that the perpetrators were other family members. Only 11 (5.4\%) women who had experienced emotional violence and 11 (6.3\%) women who had experienced physical violence had ever sought help from their doctors. In addition, only 15 (5.3\%) women who had experienced domestic violence had ever filed a complaint to the police (Table 4).

\section{Discussion}

Our analysis showed that domestic violence against women is a common problem in Oman. Detrimental effects on health and well-being, such as depression, anxiety and insomnia, were more commonly reported by women who had ever experienced domestic violence. Notably, alcohol consumption by the woman's husband was a significant predictor of the occurrence of domestic violence, although the precision of this result is low because few women's husbands drank alcohol. Despite the serious consequences of domestic violence, only a small proportion of women had ever sought help from health service providers or others.

In Oman, women play a substantial role in advancing various areas of the country's development, including participation in education, the economy and politics.
Table 1 Characteristics of the women according to experience of domestic violence ( $n=978)$, Oman, 2019

\begin{tabular}{|c|c|c|c|}
\hline \multirow[t]{3}{*}{ Characteristic } & \multicolumn{2}{|c|}{$\begin{array}{c}\text { Experienced } \\
\text { domestic violence }\end{array}$} & \multirow[t]{3}{*}{ P-value } \\
\hline & Yes & No & \\
\hline & No. (\%) & No. (\%) & \\
\hline \multicolumn{4}{|l|}{ Age group (years) } \\
\hline $18-30$ & $153(29.5)$ & $365(70.5)$ & \multirow[t]{2}{*}{0.7} \\
\hline$\geq 30$ & $129(28.4)$ & $325(71.6)$ & \\
\hline \multicolumn{4}{|l|}{ Marital status } \\
\hline Single & $51(38.1)$ & $83(61.9)$ & \multirow[t]{4}{*}{$<0.001$} \\
\hline Married & $219(26.7)$ & $602(73.3)$ & \\
\hline Widowed & $2(28.6)$ & $5(71.4)$ & \\
\hline Divorced & $10(66.7)$ & $5(33.3)$ & \\
\hline \multicolumn{4}{|l|}{ Years of marriage } \\
\hline$<5$ & $77(26.5)$ & $214(73.5)$ & \multirow[t]{5}{*}{0.7} \\
\hline $5-10$ & $81(26.8)$ & $221(73.2)$ & \\
\hline $11-15$ & $34(24.6)$ & $104(75.4)$ & \\
\hline $16-20$ & $15(30.6)$ & $34(69.4)$ & \\
\hline$>20$ & $13(29.5)$ & $31(70.5)$ & \\
\hline \multicolumn{4}{|l|}{ Number of children } \\
\hline $0-2$ & $135(25.3)$ & $398(74.7)$ & \multirow[t]{3}{*}{0.7} \\
\hline $3-4$ & $59(29.2)$ & $143(70.8)$ & \\
\hline$\geq 5$ & $16(34.0)$ & $31(66.0)$ & \\
\hline \multicolumn{4}{|c|}{ Number of people in household } \\
\hline $0-2$ & $44(26.0)$ & $125(74.0)$ & \multirow[t]{3}{*}{0.7} \\
\hline $3-4$ & $55(26.4)$ & $153(73.6$ & \\
\hline$\geq 5$ & $183(30.4)$ & $418(69.6)$ & \\
\hline \multicolumn{4}{|c|}{ Monthly family income (US\$) } \\
\hline$<1298$ & $84(36.7)$ & $145(63.3)$ & \multirow[t]{3}{*}{$<0.001$} \\
\hline $1298-2597$ & $124(25.6)$ & $361(74.4)$ & \\
\hline$\geq 2597$ & $74(28.0)$ & $190(72.0)$ & \\
\hline \multicolumn{4}{|c|}{ Educational level (participant) } \\
\hline Read and write & $0(0.0)$ & $2(100.0)$ & \multirow[t]{3}{*}{0.7} \\
\hline Up to preparatory & $26(31.7)$ & $56(68.3)$ & \\
\hline Secondary and higher & $256(28.6)$ & $638(71.4)$ & \\
\hline \multicolumn{4}{|l|}{ Educational level (mother) } \\
\hline Illiterate & $131(27.1)$ & $352(72.9)$ & \multirow[t]{3}{*}{0.7} \\
\hline Up to preparatory & $109(30.9)$ & $244(69.9)$ & \\
\hline Secondary and higher & $42(30.0)$ & $98(70.0)$ & \\
\hline \multicolumn{4}{|l|}{ Educational level (father) } \\
\hline Illiterate & $103(27.0)$ & $279(73.0)$ & \multirow[t]{3}{*}{0.7} \\
\hline Up to preparatory & $113(32.8)$ & $231(67.2)$ & \\
\hline Secondary and higher & $66(26.5)$ & $183(73.5)$ & \\
\hline \multicolumn{4}{|l|}{ Educational level (husband) } \\
\hline Illiterate & $5(50.0)$ & $5(50.0)$ & \multirow[t]{3}{*}{0.7} \\
\hline Up to preparatory & $28(33.7)$ & $55(66.3)$ & \\
\hline Secondary and higher & $195(26.2)$ & $550(73.8)$ & \\
\hline Employment (participant) & & & \\
\hline Unemployed & $152(27.1)$ & $409(72.9)$ & 0.7 \\
\hline Employed & $129(31.2)$ & $285(68.8)$ & \\
\hline
\end{tabular}


Table 1 Characteristics of the women according to experience of domestic violence $(\boldsymbol{n}=\mathbf{9 7 8})$, Oman, 2019 (Concluded)

\begin{tabular}{|c|c|c|c|}
\hline \multirow[t]{3}{*}{ Characteristic } & \multicolumn{2}{|c|}{$\begin{array}{c}\text { Experienced } \\
\text { domestic violence }\end{array}$} & \multirow[t]{3}{*}{ P-value } \\
\hline & Yes & No & \\
\hline & No. (\%) & No. (\%) & \\
\hline \multicolumn{4}{|l|}{ Employment (husband) } \\
\hline Unemployed & $6(19.4)$ & $25(80.6)$ & \multirow[t]{2}{*}{0.7} \\
\hline Employed & $217(27.2)$ & $581(72.8)$ & \\
\hline \multicolumn{4}{|l|}{ Smokes (participant) } \\
\hline Yes & $2(66.7)$ & $1(33.3)$ & \multirow[t]{2}{*}{0.7} \\
\hline No & $280(28.7)$ & $694(71.3)$ & \\
\hline \multicolumn{4}{|l|}{ Smokes (husband) } \\
\hline Yes & $23(35.9)$ & $41(64.1)$ & \multirow[t]{2}{*}{0.7} \\
\hline No & $199(26.0)$ & $566(74.0)$ & \\
\hline \multicolumn{4}{|c|}{ Drinks alcohol (participant) } \\
\hline Yes & $0(0.0)$ & $1(100.0)$ & \multirow[t]{2}{*}{0.7} \\
\hline No & $282(28.9)$ & $695(71.1)$ & \\
\hline \multicolumn{4}{|l|}{ Drinks alcohol (husband) } \\
\hline Yes & $6(85.7)$ & $1(14.3)$ & \multirow[t]{2}{*}{$<0.001$} \\
\hline No & $216(26.2)$ & $607(73.8)$ & \\
\hline \multicolumn{4}{|c|}{$\begin{array}{l}\text { In the past year, have you felt } \\
\text { sad, with loss of interest? }\end{array}$} \\
\hline No & $118(18.8)$ & $509(81.2)$ & \multirow[t]{3}{*}{$<0.001$} \\
\hline Yes, sometimes & $88(41.7)$ & $123(58.3)$ & \\
\hline Yes, most of the time & $76(54.3)$ & $64(45.7)$ & \\
\hline \multicolumn{4}{|c|}{$\begin{array}{l}\text { In the past year, have you had } \\
\text { difficulties sleeping which } \\
\text { affected your daily activities? }\end{array}$} \\
\hline No & $77(16.8)$ & $381(83.2)$ & \multirow[t]{3}{*}{$<0.001$} \\
\hline Yes, sometimes & $99(33.2)$ & $199(66.8)$ & \\
\hline Yes, most of the time & $106(47.7)$ & $116(52.3)$ & \\
\hline \multicolumn{4}{|c|}{$\begin{array}{l}\text { In the past year, have you had } \\
\text { symptoms such as abdominal } \\
\text { pain, headache, dizziness, } \\
\text { muscle pain that affected your } \\
\text { daily activities? }\end{array}$} \\
\hline No & $54(15 \cdot 3)$ & $298(84.7)$ & \multirow[t]{3}{*}{$<0.001$} \\
\hline Yes, sometimes & $96(30.1)$ & $223(69.9)$ & \\
\hline Yes, most of the time & $132(43.0)$ & $175(57.0)$ & \\
\hline
\end{tabular}

US\$ = United States dollars.

${ }^{a}$ Chi squared test.

For instance, the percentage of women pursuing higher education exceeds that of men, and nearly $60 \%$ of jobs in the education and health sectors are held by women $(18,19)$. Moreover, Oman has ratified the Convention on the Elimination of all forms of Discrimination Against Women (CEDAW) and embraced the United Nations Sustainable Development Goals (SDGs), which aim to eliminate all forms of violence against women (20). Oman has made marked improvement and progress in this field as indicated by a Gender Inequality Index value of 0.348 , which outperforms the average score of other Arab states (0.545) (21). However, currently, there is no screening programme or population-based survey to identify domestic violence against women in Oman. Furthermore, there is no specific legislation or policy that addresses domestic violence against women (22). In 2012, a shelter to protect women, who had experienced violence or abuse, was established, but access was limited only to individuals who were referred by the Prosecutor General or other law agencies (22). Some women who experience domestic violence (especially physical) report to the Ministry of Social Development directly, while others report to primary health care institutions, where their doctors will examine them and then the cases are referred to the police upon victim's request .

Our study identified an overall prevalence rate of lifetime domestic violence of $29 \%$, which lies within the range of the prevalence in other Arabic countries (4-7,23). A recent systematic review of the prevalence of intimatepartner violence in Arab countries found the prevalence ranged from $6 \%$ to $59 \%$ for physical violence and $5 \%$ to 91\% for emotional violence, although the evidence was fragmented (24). The reported prevalence in our study is lower than the prevalence in Lebanon, Saudi Arabia and Sudan $(4,7,25)$. On the other hand, our reported prevalence is slightly higher than that of Jordan and Egypt $(5,6)$. The explanation for such a variation in the prevalence of domestic violence among Middle Eastern countries could be attributed to heterogeneity in the research methodologies used and the influence of cultural differences.

Emotional domestic violence was the most common type reported by our Omani participants, which is consistent with other studies $(4,26)$. A recent study in the Islamic Republic of Iran, corroborated emotional domestic violence as the most prevalent type of violence among abused women, with more than half of the participants suffering from it (27). The reasons for such a common

\begin{tabular}{|c|c|}
\hline Variable & $\begin{array}{c}\text { No. (\%) } \\
(n=978)\end{array}$ \\
\hline \multicolumn{2}{|l|}{ Overall domestic violence } \\
\hline Yes & $282(28.8)$ \\
\hline No & $696(71.2)$ \\
\hline \multicolumn{2}{|l|}{ Emotional domestic violence } \\
\hline Mild & $102(10.4)$ \\
\hline Moderate & $38(3.9 \mid)$ \\
\hline Severe & $65(6.6)$ \\
\hline Subtotal & $205(21.0)$ \\
\hline \multicolumn{2}{|l|}{ Physical domestic violence } \\
\hline Mild & $18(1.8)$ \\
\hline Moderate & $138(14.1)$ \\
\hline Severe & $20(2.0)$ \\
\hline Subtotal & $176(18.0)$ \\
\hline Mixed domestic violence (emotional and physical) & $99(10.1)$ \\
\hline
\end{tabular}


Table 3 Logistic regression analysis of risk factors for domestic violence, Oman, 2019

\begin{tabular}{|lcc|}
\hline Risk factor & $\begin{array}{c}\text { Adjusted OR } \\
\text { (95\% CI) }\end{array}$ & P-value \\
\hline Marital status (divorced) & $1.25(0.016-95.72)$ & 0.919 \\
Low family income & $0.73(0.48-1.12)$ & 0.150 \\
Alcohol use (husband) & $9.85(1.00-96.94)$ & 0.050 \\
Feeling sad with loss of interest & $2.90(1.75-4.81)$ & $<0.001$ \\
Sleep disturbance & $2.54(1.57-4.10)$ & $<0.001$ \\
Somatic complaints & $1.73(1.08-2.78)$ & 0.022 \\
\hline
\end{tabular}

$\mathrm{OR}=$ odds ratio; $\mathrm{CI}=$ confidence interval.

finding could be explained by the fact that all other forms of violence (physical and sexual) may have an underlying emotional component (7). In addition, emotional abuse is often considered a precursor to physical abuse (28).

The negative consequences of domestic violence on health have been extensively studied (29-31). In our study, depression, anxiety, insomnia and somatic symptoms were significantly more common in women who had experienced domestic violence.

Alcohol consumption by the husband was a significant predictor of domestic violence in our sample, which is consistent with other studies $(29,32,33)$. Heavy alcohol consumption and its consequences such as aggressive behaviour and loss of self-control may lead to an impaired marital relationship and therefore a low level of marital satisfaction $(34,35)$.

The women in our study who had experienced domestic violence were more often abused by their fathers, husbands/ex-husbands or brothers. Our result is similar to what has been reported in Peru (29). Of concern is that some women had experienced violence from more than one person, and that non-partner violence is the most common form of domestic violence against women in Oman.

Despite the distressing effects of domestic violence, only a small proportion of women had sought help. This reluctance to seek help is consistent with other studies $(7,16)$ and might be due to the following reasons: (i) cultural factors and social pressures that often oblige women to consider the family as a private sphere and thereby no information should be disclosed (36); (ii) fear of retaliation by the spouse, such as separation of the mother from children; (iii) men's authority in some
Middle Eastern families (4); (iv) family belief that a man has the right to beat his wife if she disobeys him - such beliefs may increase the risk of domestic violence against women (37); and (v) underdeveloped social and health care services to address domestic violence or lack of awareness of women of the availability of such services may delay early notifications and therefore lead to more serious consequences.

Our study is among the few studies conducted in the Middle East region on domestic violence, and adds supplementary data to the existing fragmented evidence. It highlighted the magnitude of domestic violence and its association with poor health outcomes. Thus, addressing domestic violence is of utmost importance, and requires collaboration between different sectors. More investment in studying and preventing domestic violence against women in Oman is needed. This objective can be achieved through more dedicated and high-quality populationbased surveys, such as demographic and health surveys, to ensure continuous monitoring of domestic violence and reporting of SDG indicators. Different health and social programmes related to women health's issues should take domestic violence into account.

Promoting early prevention and increasing awareness of the existence of domestic violence and its detrimental effects via the media, and public and school campaigns is an important step. Similarly, strengthening the existing primary health care services by implementing a comprehensive and integrated approach for victims of domestic violence will significantly reduce their impact and burden on the community. Studies have shown that enquiring about domestic violence at the primary care level was socially acceptable and preferred by most women $(38,39)$. Health care providers must be appropriately trained to deal with cases of domestic violence in a sensitive manner and ensure that women do not feel stigmatized and their confidentiality and privacy are maintained (29). Furthermore, strengthening other formal and non-formal social services, such as counselling, shelters and hotlines for rapid access, have been effective (40).

Our study has some limitations. It was based on a self-administered questionnaire that may result in the overestimation of the true prevalence of domestic violence. Moreover, some questions related to past events depend on memory and therefore may predispose our findings to the risk of recall bias. In addition, the cross-

\begin{tabular}{lcc}
\hline Table 4 Help-seeking behaviour of women who experienced domestic violence, Oman, 2019 & Yes & No \\
\hline Help-seeking behaviour & No. $(\%)$ & No. $(\%)$ \\
\hline Have you ever tried to tell anyone about the emotional abuse that you have experienced? $(n=205)$ & $58(28.3)$ & $147(71.7)$ \\
Did you tell your doctor about the emotional abuse that you have experienced? $(n=205)$ & $11(5.4)$ & $194(94.6)$ \\
Have you ever tried to tell anyone about the physical abuse that you have experienced? $(n=176)$ & $24(13.6)$ & $152(86.4)$ \\
Did you tell your doctor about the physical abuse that you have experienced? $(n=176)$ & $15(6.3)$ & $165(93.7)$ \\
Did you file a complaint to the police? $(n=282)$ & $267(94.7)$ \\
\hline
\end{tabular}


sectional design of the study makes it difficult to derive causal relationships between variables. Furthermore, sexual violence, which is an important area that is often overlooked, was not included in our study. Finally, exclusion of the illiterate women, may have resulted in an underestimation of the true prevalence of domestic violence among Omani women.

As this is the first study about domestic violence in Oman, more studies in this field which also include illiterate women are needed to confirm our findings. In particular, studies addressing other types of domestic violence such as sexual and economic violence should be considered for future research. Exploring women's thoughts about domestic violence and the possible reasons or fears that prevent them from seeking help need to be investigated using a well-structured qualitative study.

Funding: Deanship of the Research Fund, Sultan Qaboos University, Muscat, Oman.

Competing interests: None declared.

\section{Violence domestique à l'encontre des femmes omanaises : prévalence, facteurs de risque et comportements en matière de recherche d'aide}

\section{Résumé}

Contexte : La violence domestique est un problème grave qui est souvent sous-notifié. Aucune étude antérieure sur la violence domestique n'a été menée à Oman.

Objectifs : La présente étude a permis de déterminer la prévalence et les facteurs de risque de violence domestique émotionnelle et/ou physique exercée à l'encontre des femmes omanaises, ainsi que le comportement des victimes de violence domestique en matière de recherche d'aide.

Méthodes: La présente étude transversale incluait des femmes alphabétisées âgées de 18 à 60 ans fréquentant des centres de soins de santé primaires dans la région de Mascate. Un questionnaire auto-administré a été utilisé pour enregistrer les caractéristiques des femmes et déterminer la prévalence de la violence domestique émotionnelle et physique. Une analyse de régression logistique a été effectuée pour identifier les facteurs de risque de la violence domestique.

Résultats : Sur 1051 femmes contactées, 978 ont accepté de participer. Lâge moyen des femmes était de 30,6 ans (écart type 6,9). Des violences domestiques ont été signalées par $28,2 \%$ des femmes $(282 / 978)$ dont $21,0 \%$ avaient subi de la violence domestique émotionnelle (205/978), 18,0 \% ont été victimes de violence domestique physique (176/978) et $10,1 \%$ avaient signalé à la fois les deux types de violence domestique (99/978). La violence domestique était associée de manière significative à la consommation d'alcool du mari (odds ratio $(\mathrm{OR})=9,85$, intervalle de confiance (IC) à $95 \%$ : $1,00-96,94)$ à la dépression (OR = 2,90, IC à $95 \%: 1,75-4,81)$, à l'insomnie (OR = 2,54; IC à $95 \%: 1,57-4,10)$ et aux symptômes somatiques (OR = 1,73, IC à $95 \%: 1,08-2,78)$. Seules 5,4\% des femmes victimes de violence émotionnelle (11/205) et $6,3 \%$ des femmes ayant subi de la violence physique (11/176) avaient déjà demandé l'aide de leur médecin.

Conclusion : La violence domestique émotionnelle et physique contre les femmes constitue un problème courant à Oman et elle est associée à de mauvais résultats sanitaires. Il est primordial de lutter contre ce type de violence à Oman et cela nécessite une collaboration entre les différents secteurs.

$$
\begin{aligned}
& \text { العنف العائي بين النساء العُجانيات: الانتشار، وعو امل الخطر، وسلوك التهاس المساعدة } \\
& \text { أسماء الكندي، نهور الشيذاني، مايسة الكيومي } \\
& \text { الخلفية: يُعتبر العنف العائلي من المشاكل الخطيرة التي يوجد قصور في الإبلاغ عنها. ولمجّجر أي دراسات سابقة عن العنف العائلي في عُمان. }
\end{aligned}
$$

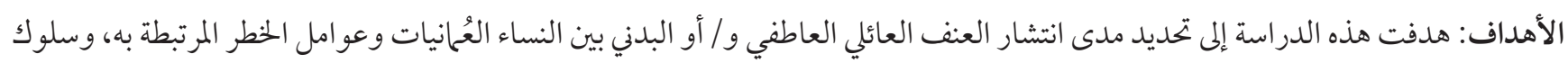

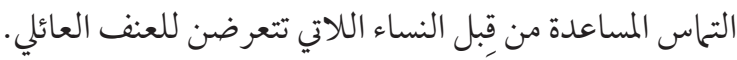

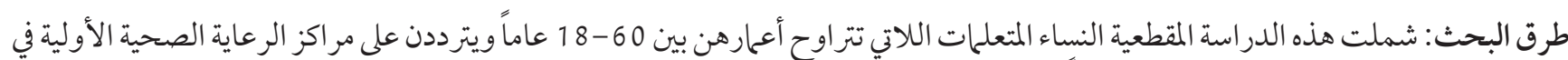

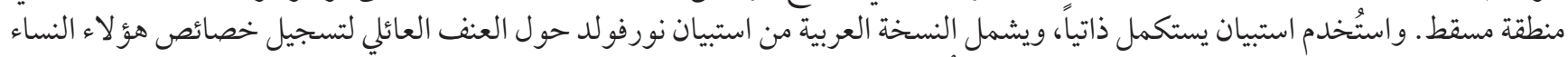

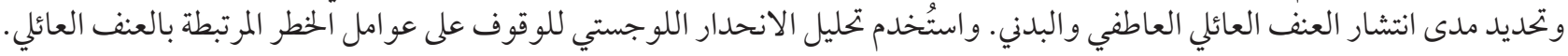

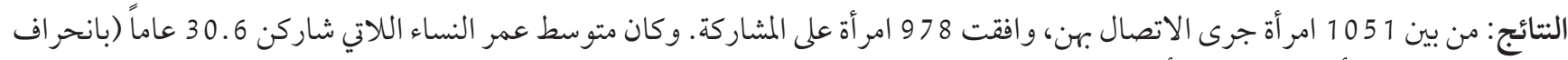

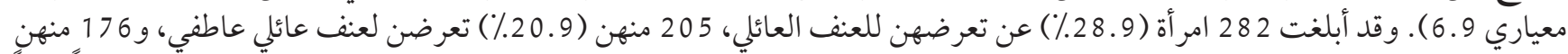

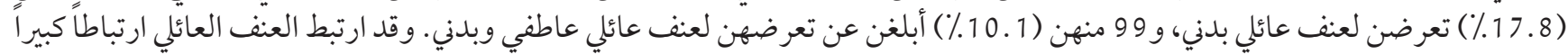




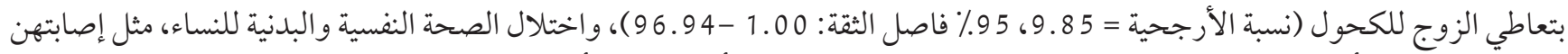

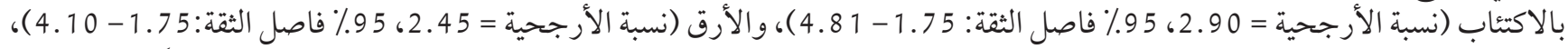

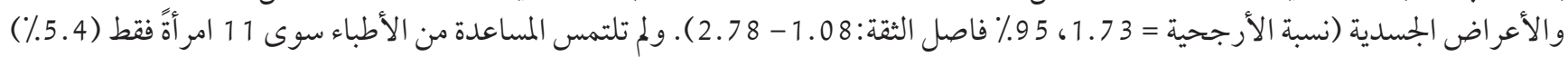

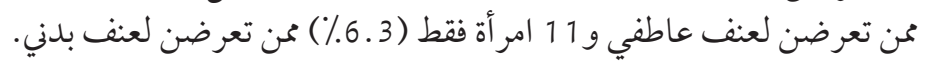

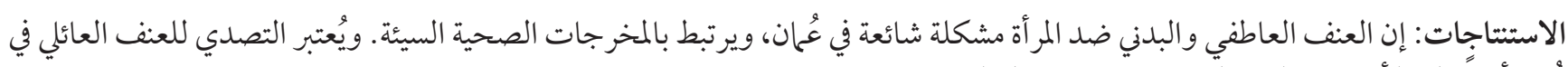

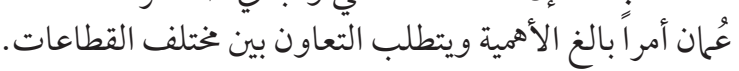

\section{References}

1. Gracia E. Unreported cases of domestic violence against women: towards an epidemiology of social silence, tolerance, and inhibition. J Epidemiol Community Health. 2004;58(7):536-7. http://doi.org/10.1136/jech.2003.019604

2. Declaration on the elimination of violence against women. New York: United Nations; 1993.

3. Violence against women. Geneva: World Health Organization; 2017.

4. Usta J, Farver JA, Pashayan N. Domestic violence: the Lebanese experience. Public Health. 2009;121(3):208-19. http://doi. org/10.1016/j.puhe.2006.09.014

5. Proportion of ever-partnered women aged 15-49 years experiencing intimate partner physical and/or sexual violence at least once in their lifetime. Amman: Department of Statistics Jordan and ICF International; 2013.

6. El-Zanaty and Associates and ICF International. Proportion of ever-partnered women aged 15-49 years experiencing intimate partner physical and/or sexual violence at least once in their lifetime. Cairo: Ministry of Health and Population and ICF International; 2015 .

7. Fageeh WMK. Domestic violence among women in Jeddah. J Womens Health Care. 2017;6(1). http://doi.org/10.4172/21670420.1000354

8. Intimate partner violence during pregnancy Geneva: World Health Organization; 2011.

9. Al-Shdayfat N. Emotional abuse among Syrian refugee women in Jordan. Global J Health Sci. 2017;9(3):237-47. http://dx.doi. org/10.5539/gjhs.v9n3p237

10. Yakubovich AR, Stöckl H, Murray J, Melendez-Torres GJ, Steinert JI, Glavin CEY, et al. Risk and protective factors for intimate partner violence against women: systematic review and meta-analyses of prospective-longitudinal studies. Am J Public Health. 2018;108(7):e1-11. http://doi.org/10.2105/AJPH.2018.304428

11. García-Moreno C, Jansen HA, Ellsberg M, Heise L, Watts C. WHO multi-country study on women's health and domestic violence against women: initial results on prevalence, health outcomes and women's responses. Geneva: World Health Organization; 2005.

12. Stöckl H, Devries K, Rotstein A, Abrahams N, Campbell J, Watts C, et al. The global prevalence of intimate partner homicide: a systematic review. Lancet. 2013;382(9895):859-65. http://doi.org/10.1016/So140-6736(13)61030-2

13. Hill A, Pallitto C, McCleary-Sills J, Garcia-Moreno C. A systematic review and meta-analysis of intimate partner violence during pregnancy and selected birth outcomes. Int J Gynecol Obstet. 2016;133(3):269-76. http://doi.org/10.1016/j.ijgo.2015.10.023

14. Al-Azri M, Al-Lawati I, Al-Kamyani R, Al-Kiyumi M, Al-Rawahi A, Davidson R, et al. Prevalence and risk factors of antenatal depression among Omani Women in a primary care setting. Sultan Qaboos Univ Med J. 2016;16(1):e35-41. http://doi.org/10.18295/ squmj.2016.16.01.007

15. nMaster 2.0. Sample size software. Vellore: Christian Medical College; 2012.

16. Haddad LG, Shotar A, Younger JB, Alzyoud S, Bouhaidar CM. Screening for domestic violence in Jordan: validation of an Arabic version of a domestic violence against women questionnaire. Int J Womens Health. 2011;3:79-86. http://doi.org/10.2147/IJWH. S17135

17. Swahnberg K, Wijma B. The NorVold Abuse Questionnaire (NorAQ): validation of new measures of emotional, physical, and sexual abuse, and abuse in the health care system among women. Eur J Public Health. 2004;13(4):361-6. http://doi.org/10.1093/ eurpub/13.4.361

18. Rethinking economic growth: towards productive and inclusive Arab societies. Beirut: International Labour Organization, Regional Office for the Arab States and UNDP Regional Bureau for Arab States; 2012.

19. Statistical year book, Oman. Muscat: National Centre for Statistics and Information; 2019.

20. Status of Arab women report 2017. Violence against women: what is at stake? New York: United Nations; 2017.

21. Human development report 2014. Sustaining human progress: reducing vulnerabilities and building resilience. New York: United Nations Development Programme; 2014.

22. UNFPA, UNDP, UN Women, ESCWA. Gender justice \& the law: Oman. New York: United Nations Population Fund; 2018 (https://arabstates.unfpa.org/en/publications/gender-justice-law-oman, accessed 10 August 2020). 
23. Maziak W, Asfar T. Physical abuse in low-income women in Aleppo, Syria. Health Care Women Int. 2003;24(4):313-26. http://doi. org/10.1080/07399330390191689

24. Elghossain T, Bott S, Akik C, Makhlouf Obermeyer C. Prevalence of intimate partner violence against women in the Arab world: a systematic review. BMC Int Health Hum Rights. 2019;19,29. http://doi.org/10.1186/s12914-019-0215-5

25. Ahmed AM, El Mardi AE. A study of domestic violence among women attending a medical centre in Sudan. East Mediterr Health J. 2005;11(1/2):164-74.

26. Afifi ZE, Al-Muhaideb NS, Hadish NF, Ismail FI, Al-Qeamy FM. Domestic violence and its impact on married women's health in Eastern Saudi Arabia. Saudi Med J. 2011;32(6):612-20.

27. Moazen B, Salehi Al, Soroush M, Molavi Vardanjani H, Zarrinhaghighi A. Domestic violence against women in Shiraz, South-western Iran. J Inj Violence Res. 2019;11(2):243-54. http://doi.org/10.5249/jivr.v11i2.1238

28. Murphy CM, O'Leary KD. Psychological aggression predicts physical aggression in early marriage. J Consult Clin Psychol. 1989;57(5):579-82. http://doi.org/10.1037//0022-006x.57.5.579

29. WHO multi-country study on women's health and domestic initial results on prevalence, health outcomes and women's response. Geneva: World Health Organization; 2005 (https:/www.who.int/reproductivehealth/publications/violence/24159358X/ en/, accessed 23 February 2018).

30. Oram S, Khalifeh H, Howard LM. Violence against women and mental health. Lancet Psychiatry. 2017;4(2):159-70. https://doi. org/10.1016/S2215-0366(16)30261-9

31. Hawcroft C, Hughes R, Shaheen A, Usta J, Elkadi H, Dalton T, et al. Prevalence and health outcomes of domestic violence amongst clinical populations in Arab countries: a systematic review and meta-analysis. BMC Public Health. 2019;19:315. https:// doi.org/10.1186/s12889-019-6619-2

32. Yusuf G, Huseyin C. Ethnic background and alcohol use of the spouse emerge as major risk factors for domestic violence: an observational study from Turkey. J Pakistan Med Assoc. 2018;68(12):1782-6.

33. Fageeh WMK. Factors associated with domestic violence: a cross-sectional survey among women in Jeddah, Saudi Arabia. BMJ Open. 2014;4:e004242. https://doi.org/10.1136/bmjopen-2013-004242

34. Homish GG, Leonard E. The drinking partnership and marital satisfaction: the longitudinal influence of discrepant drinking. J Consult Clin Psychol. 2007;75:43-51. https://doi.org/10/1037/0022-006X.75.1.43

35. Homish GG, Leonard KE. Marital quality and congruent drinking. J Stud Alcohol. 2005;66(4):488-96. https://doi.org/10.15288/ jsa.2005.66.488

36. Al-Adawi S, Al-Bahlani S. Domestic violence: "What's love got to do with it?". Sultan Qaboos Univ Med J. 2007;7(1):5-14.

37. Haj Yahia MM. A patriarchal perspective of beliefs about wife beating among Palestinian men from the West Bank and the Gaza Strip (Israel). J Fam Issues. 1998;19:595-621. https://doi.org/10.1177/019251398019005006

38. Usta J, Antoun J, Ambuel B, Khawaja M. Involving the health care system in domestic violence: what women want. Ann Fam Med. 2012;10(3):213-20. https://doi.org/10.1370/afm.1336

39. Ramsay J, Richardson J, Carter YH, Davidson LL, Feder G. Should health professionals screen women for domestic violence? Systematic review. BMJ. 2002;325(7359):314. https://doi.org/10.1136/bmj.325.7359.314

40. Bennett L, Riger S, Schewe P, Howard A, Wasco S. Effectiveness of hotline, advocacy, counseling, and shelter services for victims of domestic violence: a statewide evaluation. J Interpers Violence. 2004;19(7):815-29. https://doi.org/10.1177/088626050 